\title{
İstinat Duvarlarının Kent Kimlik Ögesi Olarak Değerlendirilmesi - Artvin Örneği
}

\section{Evaluation of the Retaining Wall as Urban Identity Element - Case of Artvin}

\author{
Dehra Eminağaoğlu, ${ }^{1}$ (1) Hilal Surat ${ }^{2}$ \\ ${ }^{1}$ Artvin Çoruh Üniversitesi Sanat ve Tasarım Fakültesi, Mimarlık Bölümü, Artvin \\ ${ }^{2}$ Artvin Çoruh Üniversitesi Sanat ve Tasarım Fakültesi, Peyzaj Mimarlığı Bölümü, Artvin
}

\section{ÖZ}

Özgün kentsel tasarım, kimlik duygusu veren, unutulmaz ve göz alıcı alanlarla, farklı yerler yaratabilir. Bir yerin kimliğini insanlar için hatırlanabilir kılan şey, yeri diğer mekanlardan ayıran özellikleri yani kendine özgü karakteri olmasıdır. Bir binanın tasarımı ne kadar iyi olursa olsun, tek başına kötü çevresini değiştiremez. Fakat iyi düzenlenmiş, yapısal ve doğal peyzaj alanlarına sahip kentsel mekanlar bir binanın tasarımındaki eksiklik veya çirkinlikleri azaltmaya katkı sağlayabilir. Kent bir bütün olarak ele alınarak çözümler üretilmelidir. Bu bağlamda kent içindeki duvarların görsel ve yapısal kalitesi bütün kent yapıları kadar önemlidir. Bu çalışmada, Artvin kent merkezine ulaşan yol boyunca yer alan duvarlar görsel kalite açısından incelenmiştir. İstinat duvarları, Artvin Kenti gibi dünyanın her yerindeki eğimli ve dağıı bölgelerin altyapısında önemli rol oynamaktadır. Çalışmada, kentte yaşayanların duvarlara ilişkin görüşleri Anlamsal Farklılaşım Metodu ile görsel olarak sorgulanmaktadır. Seçilen sıfat çiftleri ile yaşayanların her gün gördükleri duvarlara ilişkin algıları sorgulanmakta; elde edilen sonuçlar doğrultusunda duvarlar iyileştirilir ve geliştirilir ise kent için önemli bir değer olabileceği anlatılmaktadır.

Anahtar sözcükler: Artvin; duvarlar; kentsel kimlik; kentsel tasarım; istinat duvarları.

\begin{abstract}
Unique urban design can create different places with unforgettable and eye-catching spaces that give a sense of identity. What makes a place's identity memorable for people is its distinctive character, which distinguishes it from other places. No matter how good a building's design is, it can't change its bad surroundings by itself. However, wellorganized urban spaces with structural and natural landscape areas can contribute to reducing the deficiencies or ugliness in the design of a building. Solutions should be produced by considering the city as a whole. In this context, the visual and structural quality of the walls in the city is as important as all the city structures. In this study, the walls along the road to the city center of Artvin were examined in terms of visual quality. Retaining walls have played an essential part in the infrastructure of hilly and mountainous regions around the world as Artvin City. In this study, the views of the inhabitants of the city on the walls are questioned visually by the Semantic Differentiation Method. With the selected adjective pairs, the perceptions of the inhabitants about the walls they see every day are questioned. According to the results, if the walls are improved in direction with the results obtained, it is stated that it may be an important value for the city. Keywords: Artvin; walls; urban identitiy; urban design; retaining walls.
\end{abstract}




\section{Giriş}

Yaşadığımız mekanların anlaşılması, çevresel kalitenin arttırılması, mekana özgü kimliğin oluşturulmasında çevresel algının önemi büyüktür. Günümüzde modern çevreler yaratmak amacıyla oluşan mimari yapıların ve çevresel düzenlemelerin, yerel değer, anlam, kimlik, kültür kavramlarının yansımaları doğrultusunda şekillendikleri görülmektedir.

İnsanın zaman içerisinde ürettiği mimari yaklaşımlar, içinde bulunduğu doğa ve çevreye uyum sağlama çabası ile şekillenmektedir. Fiziksel ve sosyal çevreler insan davranışlarını belirleyerek, yaşadığı çevreleri biçimlendirmektedir. Kent bu çevrelerin en karmaşık ve en önemli olanıdır. Binaların dışı ile tanımlanan mekanlar, insanların gelip geçtiği, biçimlendirdiği, anlamlandırdığı yapılı çevreler kentsel mekan olarak tarif edilebilir. Kentsel mekanı sadece fiziksel olarak tarif etmek çok yetersiz olacaktır. Kentsel mekânlar, insanoğlunun bir bütünü, yapmış olduğu yaratıcılığın bir eseri, birer gündelik hayat mekânı, insan ilişkilerinin ve bu ilişkilerin gerektirdiği donatıları içeren, her anlamda paylaşılan, deneyimlenen, yaşanılan mekânlar olarak karşımıza çıkmaktadır. Bireylerin gündelik hayatlarını geçirdiği bu mekanlar, bireyin yaşamını oluşturan öznel ve psikolojik süreçleri geçirdiği, algı ve deneyimlerin bilince, kişiliğe ve anılara dönüştüğü yerler olarak inşa edilirken, kişilerin mekâna yüklediği farklı kimliklerle de şekillenmektedir (Kayapa ve Tong, 20I I: 349; Solak, 2017). Kahvecioğlu'na göre (1998) mimari mekanın, felsefede tanımlanan mekan kavramından farklı olarak, fonksiyonel ve fiziksel boyutlarının ötesinde; insan duyuları tarafından algılanan algısal boyutu, insan yaşamının özellikleri ile var olmasından kaynaklanan yaşamsal boyutu, bu yaşamsal boyutun sürekliliğine bağlı olarak oluşan bir kültürel boyutu da barındırabilen mekanlar olarak tanımlanmaktadır. Kentsel mekânlar, bu yönüyle hem kentin kamusal benliğini ve kimliğini inşa etmekte hem kişilerin kimliğini ve kişiliğini şekillendirmektedir (Solak, 2017). Böylece insanlar kentsel bir mekanı algılarken statik bir mekan anlayışını benisemek yerine, kentsel mekanı deneyimlenerek var edebilen bir anlayışı benimsemiştir. Kısacası insan yaşadığı kentin fiziksel yapısını anlamlandırmakta, seçmekte ve zihinde örgütlemektedir (Göregenli, 20l0).

Kentsel bellek ile mekan arasındaki etkileşim, bireylerin kentsel mekanı algılama biçimleri ve farklılıklarıyla zenginleşmektedir. Burada kolektif belleği etkileyen unsurlar anılar, dil, geçmiş ve kültür olarak belirirken, kentsel mekan kendine özgü özellikleri ve yerelliği ile odak haline gelmekte ve söz konusu ilişkiler ile sürekli var olmaktadır (Ünlü, 20l7). Bu görüşlere temel kaynak olarak gösterilen Genius Loci'de (N.Schulz, 1980) alanın kendine ait karakteristiğinden bahsedilmektedir. N.Schulz bu yapıtında doğal ve insan ürünü olmak üzere alanı (space) ayrı ayrı tanımlamaktadır. Yine N Schulz'un Existence, Space and Architecture isimli yayınında (N.Schulz, 197I) insan ve çevresi arasındaki temel ilişkiler, "mekan”, "karakter" ve "kimlik” sorunları ile ortaya konmaktadır. Mekânın anlamı, genelde fiziksel açıdan işaretlerle, malzemeyle, renklerle, biçimlerle, büyüklüklerle, mobilyalarla, peyzaj vb. somut öğelerin etkileriyle oluşmaktadır. Bu somut öğeler zihinsel haritalarda yerini alırken psiko-sosyal durumlarla yorumlanarak hem kişilerin hem de kentlerin kolektif belleğinde mekânın anlamını oluşturmaktadır (Solak, 2017).

Literatürde imaj / imge çalışmaları; çevrenin kişilerce kullanılan ve deneyim kazanılan yönünü vurgularken, kentin biçimlenişindeki önemi ve yansımalarını araştırmaktadır. Lynch'e göre iyi ve doğru imajların oluşabilmesi için, düzenli ve tanınabilir mekanlar-okunabilirlik gereklidir. Bir yerin kimliğini insanlar için hatırlanabilir kılan unsur, yeri diğer mekanlardan ayıran özellikleri yani kendine özgü karakteri olmasıdır (Lynch, 198I, 1960) Relph'e ( 1976) göre, bir mekanın niteliği mekan ile kurulan etkileşim, insan düşünceleri, davranışları ve deneyimlerine bağlı olarak gelişir. Tversky’e göre insanın mekan içinde etkin olabilmesi için, mekanın zihinsel imgelere sahip olması gerekir. Bu imgeler yoluyla, belirli bir referans çerçevesinde mekansal ilişkileri algılayabilir; bu algılanan yapı içerisinde amaca bağlı olarak değişen biçimlerde davranabiliriz (Tversky, 2000). İnsanın doğal çevresini ve yaşam çevresini öğrenmesi, kodlaması yönünde oluşan yapı-mekan, daha çok insanın çevrede yön bulması üzerine biçimlendirilmiştir (Göregenli, 20l0).

Yapılı çevre elemanları, kentlerde süregelen insan gereksinimlerinden kaynaklanan eylem alanları ve bu eylem alanlarının karşılıklı ilişkileri ve kültürel yapıyla biçimlenen objelerden oluşmaktadır. Kentte yapılaşmış her öge kimlik elemanı olarak değerlendirilemez. Bu kent ögeleri, konumsal, biçimsel, işlevsel ve anlamsal değerlere sahip olmalıdır (Ocakcı ve Türk, 20I2).

Kişi, bulunduğu mekanlar ile arasında oluşan etkileşim sonucunda anlamlandırdığı mekânları çevresel imgelere dönüşmektedir. Bu çevresel imgeler üç bileşenden (kimlik, yapı ve anlamdan) oluşmaktadır (Lynch, 2010, Solak, 2017). Günümüzde kentlerin planlanmasında arazi kullanımı ve imar haklarını ön planda olduğu, bütün ile parçalar arasındaki ilişkinin kurulamadığı, kent imgelerinin tartışılmadığı, tasarım endişelerinden uzak, kentlerin üst-biçimlerine hâkim olan mekanik bir planlama anlayışı benimsenmiştir (Baykan, 2006). Kentin genel kurgusuna ilişkin yaklaşımlar mevzuata bağlı tanımları aşamamakta; kentin geleceğiyle ilgili farklı kimlik alanlarını öne çıkaran düzenlemeler yetersiz kalmaktadır. Mimari tasarım ve çevre etkileşimi içerisinde, "alan (space)" kavramı ile bütünleşecek nitelikli mekânların oluşturulması mekan ve kent kimliği açısından önemlidir.

Kente özgü bir kimlik oluşturabilmek için mevcut çevre bileşenlerini değerlendirmek gerekmektedir. Önemli olan çevrenin kalitesinin kullanıcı tarafından algılanış şeklidir. Çevresel 
nitelikler Nasar (1988) tarafından, Doğallık, bakım, açıklık ve tanımlanmış mekan, tarihsel önem/içerik, düzen şeklinde son derece genelleştirilmiş tercihler serisine dönüştürülmüştür (Inceoğlu ve Aytuğ, 2009).

Kentin doğal yapısında var olan veya kentin biçimlenmesinde rol oynayan çevresel özellikler, kente özgü mekan bileşenlerini ortaya çıkarır. Arazi biçimi yerin karakteristik yapısını ve özelliğini belirleyen, biçimsel imgelerin oluşmasında belirleyici bir çevre bileşenidir. Dağ, orman, çöl, düz-eğimli arazi gibi karakteristikler, yerin kimliğine ve yeni imajların oluşmasında referans olarak kentin gelişimine katkı sağlamaktadır.

Bu çalışmada; eğimli topoğrafyanın zorunlulukları ile gelişen ve oluşan bir yerleşme yapısı içindeki istinat duvarları ele alınmaktadır. Her gün bir şekilde geçtiğimiz yol güzergahları üzerinde oluşan duvarlar koruma, sınırlama, mahremiyet, yönlendirme gibi işlevlerinin yanında, bulunduğu konuma estetik kaliteler getiren yapısal elemanlardır (Bayraktar vd., 2008; Başal ve ark., 1993; Tanrıverdi, 200I). Kent içindeki duvarlar yatay ve düşey yönde etkili mekan hissi yaratmakta (Uzun, 1997); ölçeği, malzemesi, renk ve dokusuyla bulundukları konumun tanınabilirliğini güçlendirmektedir. Bu kapsamda eğimli topoğrafyaya sahip Artvin Kenti'nin genel yerleşim strüktüründe vazgeçilemez bir mekan bileşeni olan, yol güzergahları boyunca görülen duvarların kent imgesindeki algısı incelenecektir.

\section{Çevresel Algı ve Kentsel Kimlik İlişkisi}

Görsel mekan algısı insanı ele alan süreçlerle ilgili olarak, dış dünyanın olaylarını ve objelerini zihinde kopyalayan psikolojik bilişsel bir süreçtir (Szostak, 2010). Zihinsel kimlik, mekan algısı ile mekansal bilgi oluşturma arasındaki bağlantıdır. Algılanan bilgilerin seçimi ve yorumlanması kültürel ve kişisel filtreler tarafindan yapılır (Rapoport, 1990) ve yerleşik kültürel kalıplara atıfta bulunulur (Alexander et al, 1977).Çevrenin algılanması, öğrenilmesi ve değerlendirilmesinin sürekliliği, çevrenin duyu organları ile algılanması ve çevrenin niteliklerinin tanınması sonucunda, seçim yapma, karar verme sürecidir (Rapoport, 1990). Kişilerin mekânı değerlendirmesinde mekânsal algının önemli bir rolü vardır. Bu değerlendirmeler, kişinin o mekândaki davranışlarını etkiler ve şekillendirir. Kişinin mekân içerisinde veya çevresinde kısa veya uzun süreli deneyim kazanması ve bu doğrultuda mekânın hatırlanması mekân algısı ile ilgilidir (Özen,2006). Algılama süreci, duygusal tavır ve eğilimler ile birlikte gerçekleşmekte; nesneye ilişkin algılama sevme, sevmeme, iyi, kötü, korkma vb. gibi duygusal nitelikteki birtakım izlenimlerin etkisiyle oluşmaktadır (Inceoğlu, 2010). Yani bireylerin duygusal ve sezgisel anlamdaki eğilimleri, yaşam deneyimleri ve çevresel faktörler altında ortaya çıkmakta; bu durum algılama sürecini olumlu veya olumsuz etkilemektedir.
Kent kimliği, doğal ve yapısal çevrenin yanısıra sosyo-kültürel yapının karşııkılı etkileşimi sonucu oluşur. Kent kimliğini oluşturan öğelerin belirlenebilmesi için, öncelikle çevrenin doğru tanımlanması gerekir. Çevreyi tanımlamak için, çevre bir bütün olarak derinliğine kavranıp, bir bütün halinde değerlendirilmelidir. Bir bütünü oluşturan parçaların her birinin ayrı bir özelliği ve kimliği vardır. Bu ayrı parçalar birleşip bütünü oluşturduğunda ise, o bölgeye ait kimlik oluşur. Bölgenin kimliğinin tam olarak belirlenebilmesi için, parçaların analiz edilerek çıkan sonuçlara göre kimlik tanımlanmalıdır (Önem ve Kılınçaslan, 2005).

Kent görüntüsünü oluşturan doğal ve yapay elemanlar ile insanların bireysel ve kollektif algısı arasında yakın bir ilişki vardır. Kent içerisinde tekrarlanan ögeler, tekrarlanan olaylar, tekrarlanan kullanımların bellekte yarattığı izler, kent kimliğini oluşturmaya katkıda bulunabilir. Bireylerin çevrelerine yönelik algıları, belleklerinde oluşan izlenimler açısından önemlidir. Kamusal alanlardaki çevresel algı faktörlerinin, fiziksel çevre kalitesi ile ilişkisi değerlendirilerek mekanın önerilen anlamları keşfedilebilir.

\section{Kentsel Mekan Öğesi Olarak Duvarlar}

Yaşadığımız çevrelere ilişkin algılarımız ile beslenen kentsel mekandaki deneyimlerimiz, kent kimliğinin oluşmasına önemli katkılar sağlar. Kentsel mekân, halkın rahatlıkla ulaşabildiği yapııı ya da doğal olan binaların dışında kalan çevreleri ifade etmektedir. Kent dokusunu oluşturan kentsel mekânlar birbirlerine Kamusal kullanımlara imkan veren caddeler, sokaklar, meydanlar, parklar ulaşım sistemleri ile bağlanmaktadır. Lynch, mekân algııı kavramını kent ölçeğinde ele alarak, kentsel algının önemine, kullanıcının kenti okuma ve anlamlandırma süreci üzerine çalışmalar yapmıştır. Kent mekânın algılanması için gereken bileşenleri kentsel imaj öğesi /kent imgesi bileşenleri olarak yollar, bölgeler, sınırlar, düğüm/odak noktaları ve işaret öğeleri olarak sınıflandırmıştır (Lynch, 2010: 5I-87). Düğüm noktaları ve bağlantılar, günlük hayatta yayaların içinde hareket ettikleri kentin yapısını oluşturan kentsel mekânlardır. Ulaşım, araç ve yaya hareketlerini kapsayan, belirli bir amaç için insanların ve eşyanın mekanda yer değiştirmesidir. Kentsel mekan kullanımları yönünden farkli olan kentteki iş ve konut alanları ile sosyo-kültürel alanlar birbirleri ile olan ilişkilerini sağlayan ulaşım, kentsel yaşamın önemli unsurlarından biridir. Cadde ve sokaklar, kentsel mekanları bağlamaları ve hareket kanalları olmaları itibariyle gündelik yaşamda her insanın kullandığı kentsel mekanlardır. Eğimli araziler üzerine yerleşmiş kentlerde cadde ve sokkakların vazgeçilmez unsuru ise eğimli arazi ile arasında sınır oluşturan duvarlardır. Duvarlar sözkonusu bu ulaşım mekanları için önemli yapısal elemanlardır. Bu çalışmada, kente ulaşmak için her kişinin mutlaka kullandığı kent içi ulaşım güzergahındaki en önemli yapısal elemanlardan biri olan duvarların kişiler üzerinde bıraktığı izlenimler algısal 
bir sorgulama ile incelenmektedir. Kentin mekansal gelişimi ve kent kimliğinde belirleyici olan mekansal bileşenlerin, kentlilerin belleğinde yer alıp almadığı sorusundan hareketle bu çalışma gerçekleştirilmiştir.

Duvar kelimesinin toplumsal bilinç üzerinde sembolik değeri değişebilir. Fakat yerleşik hayata geçiş ile birlikte sınırlar oluşturan duvarlar yapı mirası olarak kabul edilebilir. İlk insanlar; çevresel koşullardan, yabani hayvanlardan ve düşman topluluklardan korumak amacıyla duvarlar inşa etmiş, uçsuz bucaksız boşluğu sınırlandırmıştır. Mekanı tanımlamanın yanı sıra, iç ile dışın ilişkisini ve mekanın karakterini belirleyen önemli bir yapı bileşendir. Yapı bileşeni olan duvarlar zaman içerisinde sadece mekanı sınırlamakla kalmayıp, savunma amaçlı, kentleri de sınırlamıştır. Örneğin, Pekin kenti dünyanın en uzun savunma duvarı olan Çin Seddi ile anılan bir değere ulaşmıştır.

Bugün gelinen noktada insanlık toplumsal evrimini yaşarken duvarlar inşa etmeye her zamankinden daha fazla ihtiyaç duymakta, daha büyük, daha uzun, daha sağlam duvarlar inşa etmektedir. Duvarlar, bazen basit bir ayrım yaparken, bazen güç göstergelerine dönüşmekte, hatta ideolojileri simgelemekte, toplumların ruhunda yer etmektedir. Soğuk Savaş'ın simgesi olarak yıllarca varlığını sürdüren Berlin Duvarı, Doğu Berlin halkının mutsuzluk ve umutsuzluk anıtına dönüşmüş beton bir sınır iken; yıkılması insanları sevinç gözyaşlarına boğmuştur. $\mathrm{Bu}$ denli anlamlar, görevler yüklenen duvarların arasında yaşarken bu yapılara ilgi artmıştır. Sokak sanatçıları grafitiler aracılığı ile duvarları sanat alanı olarak kullanmış; isyanlarını, ideolojilerini, aşklarını duvarlara işlemiştir. "Wall art" sanat akımının çıkış noktasını oluşturan estetik kaygılar ile niteliksiz duvarlar, bakmaktan zevk alınan ve başka insanlarla iletişim kurmayı sağlayan mekanlara dönüşmektedir.

Doğal çevre faktörleri kentlerin fiziksel biçimlenişine yön veren önemli veriler sunar. Bu verileri kente özgü yapısal değerlere dönüştürmek kent kimliği açısından önemlidir. Kent içinde sınırlar oluşturan duvarlar işlevsel ve biçimsel açıdan çok farklı amaçlarla kullanılmaktadır. Özellikle eğimli arazilerde, şevlerde zeminin kaymaması için yapılan istinat duvarları, hareket boyunca insanlara eşlik etmekte; yaşam alanları oluşturmaktadır. Doğal ve yapılı çevrelerle olan birliktelikleri farklı ve sürekli görüntüler sunmaktadır. Kentin fiziksel yapısını biçimlendiren duvarların yol güzergahlarındaki yoğunluğu araştırma alanı içerisinde dikkat çekmekte ve önemli bir yapı elemanı olarak karşımıza çıkmaktadır. Bu açıdan bakıldığında duvarların algılanabilirliği ve tanınabilirliği kent kimliği açısından önemlidir.

\section{Araştırma Alanı}

Araştırma alanı olarak seçilen Artvin İ Merkezi kuzeyinde Borçka, kuzey doğusunda Şavşat, kuzey batısında Murgul, gü-

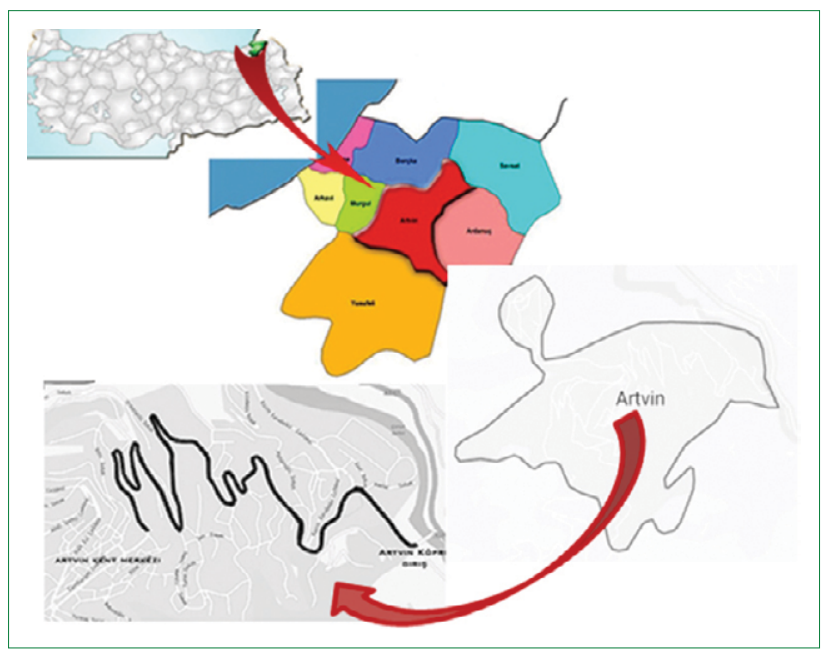

Şekil I. Çalışma alanı.

neyinde Yusufeli ilçeleri ile sınırlanmıştır (Şekil I). İlin yüzölçümü 7436 km²

Artvin İli bütün olarak dağlık bir yapıya sahiptir. Kent, Çoruh vadisi boyunca bulunan taban arazilerden başlayıp, yüksek dağ yamaçlarında bulunan orman arazilerinin açılması ile oluşan arazilere kadar olan dağlık ve oldukça eğimli bir topoğrafya üzerine konumlandırılmış ve yaklaşık 600 metre (I75 m-780 $\mathrm{m})$ kot farkına sahiptir. Bu sebeple kentin fiziksel biçiminin yayılımı dağlar, tepeler, yamaçlar ile sınırlandığı için, kent dokusu, yapı yoğunluğunun artışı şeklinde gelişme göstermektedir. Bu da çalışma alanında eğimli coğrafya ve yapı yoğunluğu ilişkisinin ele alındığında yapılaşmanın olduğu alanlarda kat artışı ile birlikte taban alanlarının genişlemesine paralel istinat duvarları ortaya çıkmıştır (Eminağaoğlu ve Yavuz 2005).

Artvin kenti genel olarak göç veren bir kent durumundadır. Tarım ve hayvancılık faaliyetlerinin kısıtlı olması, endüstriyel faaliyetlerin olmaması gibi nedenler kent için alternatif gelir kaynakları arayışını ortaya çıkarmaktadır. Bu bağlamda kentin doğal ve kültürel varlıkları turizm potansiyeli açısından gündeme gelmektedir. Böylesi bir durumda kent kimliğine katkı sunan unsurlar turizm açısından önemlidir.

\section{Materyal ve Yöntem}

İnsanların kent içerisindeki mekan öğeleri ile etkileşimleri ve algılanmaları arasındaki ilişkileri ortaya koyabilmek için deneysel bir çalışma yapılmıştır. Yapılan çalışmada yaya ve araç güzergahındaki duvarlar sadece görsel açıdan ele alınmış olup, yapısal özelliklerin değerlendirilmesi araştırma kapsamı dışında tutulmuştur. Araştırmada, yerinde gözlem, veri toplama, analiz ve değerlendirme yöntemleri kullanılmıştır. Araştırma alanı; Artvin İli Kent merkezii köprü başı mevkiinden, Şehir Merkezi arasındaki 2.5 km'lik alanı kapsamaktadır. Bu alan, yol boyunca duvarların yoğun olduğu ve kent merkezine ulaşılan tek güzer- 


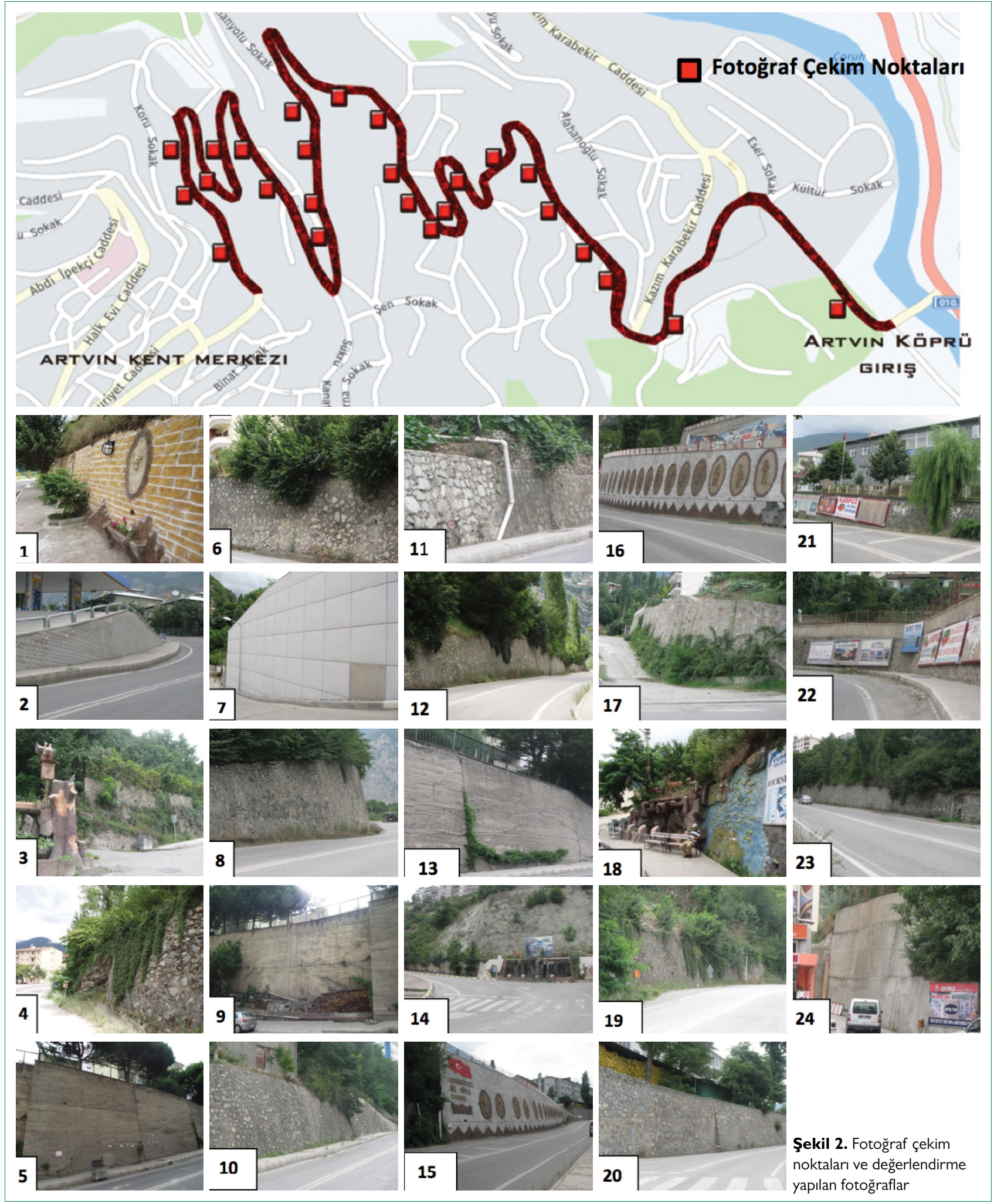

gah olduğu için, her kesimin mutlaka kullandığı bir yol güzergahıdır (Şekil 2). Özellikle yamaç yerleşmelerinde bir zorunluluk olarak kullanılan istinat duvarlarının ulaşım güzergahlarında oluşturduğu görüntülerin kent için kimlik değeri oluşturacağı varsayımından yola çıkılarak, duvarların insanlar üzerindeki etkileri, görsel izlenimler algısal düzeyde ortaya konulmuştur. 
Tablo I. Örneklem büyüklüğünün hesaplanmasında kullanılan formül

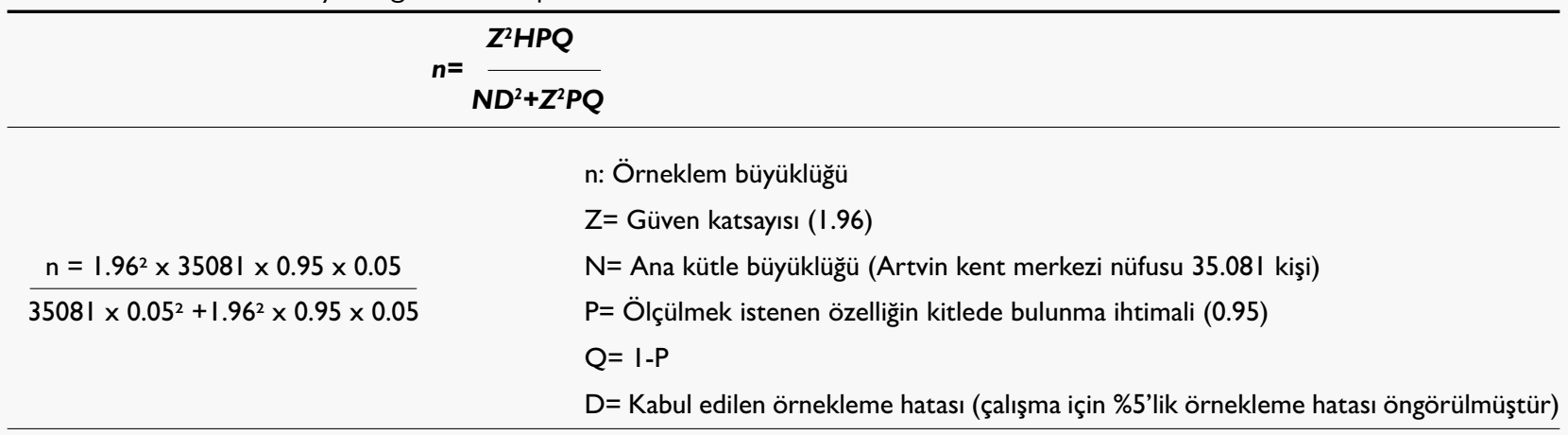

Yapılan çalışmada, kentin önemli bir parçası olan kent içindeki yol üstü duvarların algısal düzeyde sorgulanması Anlamsal Farklılaşım Ölçeği tekniği kullanılarak elde edilen veriler doğrultusunda değerlendirilmiştir. Her bir fotoğraf için parametrelerin belirlenmesinde konu ile ilgili literatürlerin yanı sıra Osgood ve diğ. (1957) tarafından geliştirilen Acar vd., 2003 tarafından çalışmalarında kullanılan zıt parametrelerden oluşan çizelge ile ifade edilen farklılaşım ölçekleri kullanılmıştır.

Anket aşaması ve Anlamsal Farklılaşım Ölçeği çalışması için, Artvin halkı arasından belirlenen kent sakinleri katılımcı olarak seçilmiştir. Örneklem büyüklüğünün saptanmasında Kalıpsız (I98I) tarafından kullanılan Tablo I'de verilen formülden yararlanılmıştır. Artvin kent merkezi nüfus büyüklüğü 35.08I kişi sayısı (Anonim, 2017a) dikkate alınarak \%95 güven aralığında ve aşağıda verilen formül kullanılarak 73 kişi olarak belirlenmiştir (Tablo I).

Katılımcıların çoğunluğu söz konusu aksı taşıt aracı ile sürücü olarak kullanan kişilerden basit tesadüf örneği (simple random sampling) yöntemi kullanılarak seçilmiştir. Bu çalışmada, I 8 yaş üstü kişiler ile anket çalışması yapılmıştır. Aks boyunca ortalama taşıt hızı yasal hız sınırı olan 50 km/h'tır. Aksı yaya olarak kullanan katılımcılar ise aks boyunca yerleşim alanlarında ikamet eden kişilerdir. Algı ve değerlendirmenin yaş, cinsiyet, eğitim düzeyi, araştırma alanını kullanım sıklığına göre değişeceği düşünülerek öncelikle anket uygulanmıştır.

Fotoğraflar, katılımcılara dikkatlice incelemeleri ve sorulara göre değerlendirmeleri için gösterilmiştir. Çalışmada kullanılan fotoğraflarda konuya ilişkin alternatif çözümler üretebilmek için duvarlara ilişkin temel bileşenler belirlenmiştir. Duvarlar yapı malzemesi (doğal taş, beton, vb.), ölçü (yükseklik ve uzunluk), üzerinde bulundurduğu objeler (bitki varlığı, afış, reklam panosu, tesisat boruları, dekoratif figürler vb.) açısından incelenmiş; bu özellikleri dikkate alınarak fotoğraflanmıştır.

Çalışma alanı olarak belirlenen yol güzergahı üzerindeki I I noktadan toplam $2 \mathrm{~km}$ uzunluğundaki istinat duvarlarının gör- sel açıdan değerlendirilmesi amacıyla yaklaşık I00-I 50 adet fotoğraf çekilmiştir. Fotoğraflar otoyol üzerinde saatte ortalama 50 km yasal hız sınırı esas alınarak araç içerisinden çekilmiştir. Bu çekilen fotoğraflarda saatte $50 \mathrm{~km}$ hızla giden bir araç içindeki sürücünün görüş alanı içerisindeki istinat duvarlarının malzeme, obje, yükseklik, süreklilik özelliklerinin net görülebildiği (Tablo 2) açılardan fotoğraflar çekilmiştir. Çekilen bu fotoğraflardan bu özellikleri yansıtabilen en uygun 24 âdeti değerlendirmede kullanılmıştır. (Şekil 2). Ankete katılan katılımcılardan her bir fotoğrafı, belirlenen parametrelere göre değerlendirmeleri istenmiştir. Değerlendirilmeye alınan istinat duvarlarının karşısında yapılar (konut, ticaret, vd.), mevcuttur.

Kalmbach ve Kielbaso (1979); Arriaza vd., (2004); Acar ve Günerioğlu (2009); Eren vd. (20I8) çalışmalarında kullandıkları değerlendirme parametreleri arasında çalışmanın içeriğine uygun olduğu düşünülen (Çirkin-Güzel, Karmaşık-Sade,SıkıcıRahatlatıcı, Sıradan-İlginç, Bakımsız-Bakımlı, Yapay-Doğal, Yorucu-Dinlendirici, Etkisiz-Etkili, Hareketli-Monoton) parametreler seçilerek, 24 fotoğraf aşağıdaki tabloda verilen ölçek doğrultusunda puanlanmıştır (Tablo 3). Anlamsal Farklılaşım Ölçeği kullanılarak Tablo 3'teki parametrelere göre katılımcıların duvarlara yönelik görsel algılarını değerlendirmek amacıyla beğenileri istatistiksel değerlendirme teknikleri açısından I-7 değerlerine dönüştürülmüştür. Değerlendirme ölçeğinde I'e yaklaştıkça beğeni azalmakta, 7'ye yaklaştırkca beğeni artmaktadır. 4 ortalama bir beğeniyi ifade etmektedir.

Araştırmada, katılımcıların özellikleri ve duvar fotoğrafları için verdikleri GKP'nın (görsel kalite puanı) ortalamaları alınmıştır. GKP'nında (görsel kalite puanı) hangi parametrelerin en etkili olduğunu belirlemede regresyon analizi kullanılmış; parametreler arasındaki ilişkiyi ortaya koyabilmek için parametrik olmayan korelasyon analizleri SPSS istatistik programında gerçekleştirilmiştir.

\section{Bulgular}

Artvin Kent Merkezi arazi eğiminin fazla olduğu, birçok uygulama alanında standartları zorlayan yapısal düzene sahip ol- 
Tablo 2. Fotoğrafların değerlendirmede ön planda olan özellikleri

\section{Değerlendirmede kullanılan fotoğrafların temel bileşenler/özellikleri}

I Yp/dekoratif figürler

$2 Y \mathrm{p}$

3 Yp/dekoratif figürler-bitki varlığı

4 Yp/bitki varlı̆̆ı

5 Yükseklik

6 Yp/bitki varlığı

7 Yp/yükseklik

8 Yp/bitki varlığ/süreklilik

9 Yükseklik/süreklilik

10 Yp/süreklilik

II Yp/obje

I2 Bitki varlığı/yükseklik/süreklilik

13 Yp/yükseklik

I4 Afiş, reklam panosu/süreklilik

15 Dekoratif figürler/süreklilik

16 Dekoratif figürler/süreklilik

17 Yp/bitki varlığı

$18 \mathrm{Yp} /$ dekoratif figürler-

19 Yükseklik/süreklilik

20 Yp/süreklilik

2I Afiş, reklam panosu

22 Afiş, reklam panosu

23 Yp/bitki varlığı/yükseklik/süreklilik

24 Yükselklik/süreklilik

Yp: yapı malzemesi (doğal taş, beton, vb.); ölçü (yükseklik ve uzunluk); üzerinde bulundurduğu objeler (bitki varlığı, afış, reklam panosu, tesisat boruları, dekoratif figürler vb.).
Tablo 3. Anlamsal farklılaşım ölçeği

\begin{tabular}{lcccccccc}
\hline Parametreler & $\mathbf{- 3}$ & $\mathbf{- 2}$ & $\mathbf{- I}$ & $\mathbf{0}$ & $\mathbf{I}$ & $\mathbf{2}$ & $\mathbf{3}$ & Parametreler \\
& (1) & $\mathbf{( 2 )}$ & $\mathbf{( 3 )}$ & $\mathbf{( 4 )}$ & $\mathbf{( 5 )}$ & $\mathbf{( 6 )}$ & $\mathbf{( 7 )}$ & \\
\hline Çirkin & & & & & & & & Güzel \\
Karmaşık & & & & & & & Sade \\
Sıkıcı & & & & & & Rahatlatıcı \\
Sıradan & & & & & & İlginç \\
Bakımsız & & & & & & Bakımlı \\
Yapay & & & & & & Doğal \\
Yorucu & & & & & & Dinlendirici \\
Etkisiz & & & & & & Etkili \\
Monoton & & & & & Hareketli \\
\hline
\end{tabular}

makla birlikte, yamaç yerleşmesi olarak dikkat çekici bir kent formuna sahiptir. Araştırma alanı ve çalışmaya konu olan duvarlar topoğrafik yapının getirdiği bir koşuldur.

Ana cadde üzerinde dikkat çeken öğeler gruplandırıldı̆̆ında duvarlar \%42,7 oranı ile en fazla dikkat çekmektedir. \%30, I oranı ile yapılar ve $\% 27,2$ oranı ile doğal elemanlar sıralanmaktadır. Duvarların yol güzergahında tek yönlü olarak görüş mesafesini kısıtlaması dikkat çekiciliğini zorunlu olarak arttırmaktadır.

Çalışma kapsamında araştırma alanı içerisinde belirlenen duvar örneklerine verilen tercihlere bakıldığında; en fazla 23 no'lu fotoğraf 4,59 (GKP) görsel kalite puanı ile diğerlerine göre daha çok beğenilmiştir. Bu fotoğrafı 4,26 (GKP) görsel kalite puanı ile 12. fotoğraf, 3,97 (GKP) görsel kalite puanı ile 6. Ve 14. Fotoğraf, 3,90 (GKP) görsel kalite puanı ile 17. fotoğraf izlemiştir. Buna karşın I,87 (GKP) görsel kalite puanı ile 22. fotoğraf en az beğenilen fotoğraf olmuştur (Şekil 3).

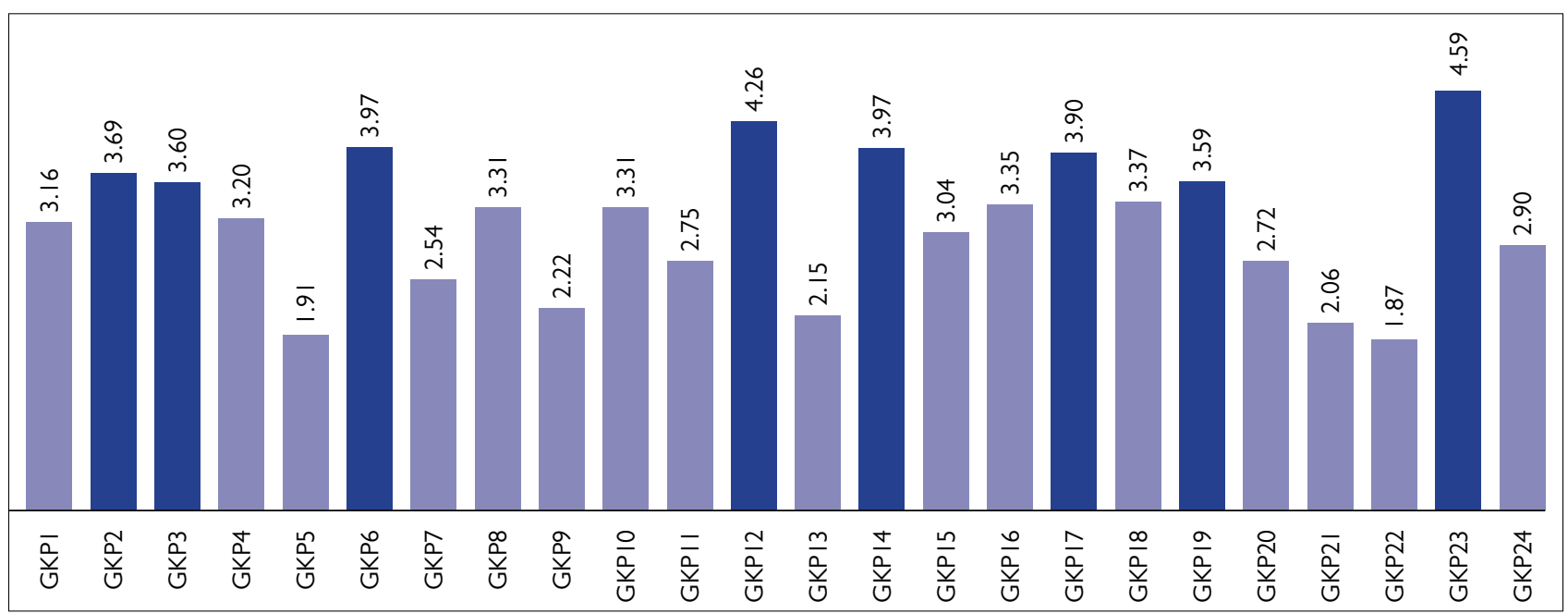

Şekil 3. Değerlendirmesi yapılan istinat duvar resimlerinin görsel kalite puanları. 


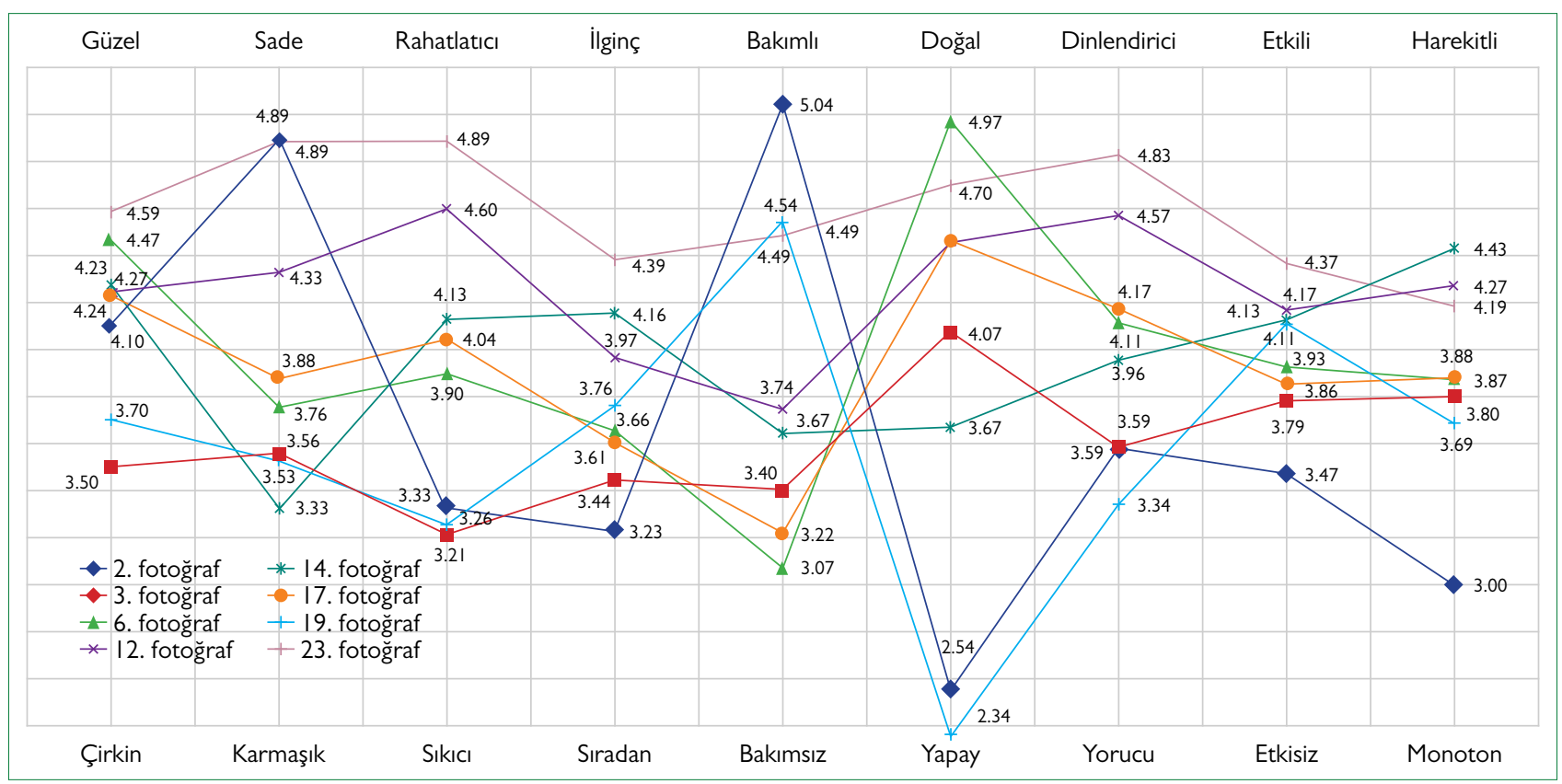

Şekil 4. Görsel kalite puanı yüksek olan 8 fotoğrafa ait anlamsal farklılaşım sonuçları.

Görsel Kalite Puanı en yüksek olan 23 nolu fotoğraftaki istinat duvarı; katılımcılar tarafından sade, rahatlatıcı, dinlendirici, doğal, güzel, ilginç, etkili, bakımlı ve hareketli bulunurken en düşük puanı alan 22 nolu fotoğraftaki istinat duvarı çirkin, sıkıcı, bakımsız ve etkisiz bulunmuştur. Bunun yanı sıra görsel kalite puanı yüksek olan 2 nolu fotoğraftaki istinat duvarı; güzel, sade, bakımlı bulunduğu; 6 nolu fotoğrafın doğal, güzel ve dinlendirici bulunduğu; 12 nolu fotoğrafın rahatlatıcı, dinlendirici, doğal, sade, hareketli, güzel ve etkili bulunduğu; 14 nolu fotoğrafın hareketli, güzel, ilginç, etkili ve rahatlatıcı bulunduğu; 17 nolu fotoğrafın doğal, güzel, dinlendirici ve rahatlatıcı bulunduğu tespit edilmiştir (Şekil 4).

Özellikle kentsel peyzaj görüntüleri üzerinde yapılan çalısmalarda doğal malzemeler insan psikolojisi üzerinde etkili olduğu görsel kaliteyi ve tercih edilirliği arttırdı̆̆ı belirtilmiştir (Arriaza vd. 2004; Val vd., 2006; Dascalu, 20I I; Aksu, 2012). Mekanı oluşturan fiziksel öge ve bileşenlere doğallık özelliği kazandıran tüm unsurlar (malzeme, obje, doğal eleman varlığı, doğal fiziksel yapı vb), mekânların estetik kalitesi üzerinde pozitif etki yaratmaktadır (Karaşah ve Sarı, 2015). Örneğin; 23 nolu fotoğraftaki duvarın sahip olduğu doğal objelerin (yeşil doku) ve duvarda kullanılan doğal taş malzemenin görsel kaliteyi arttırdığı tespit edilmiştir. Ayrıca doğal malzemenin etkili olduğu ve görsel kalitesi yönünden yüksek puan alan 6 ve 12 nolu fotoğraftaki duvarların aynı zamanda bakımlı, sade ve güzel olduğu tespit edilmiştir.

Süreklilik ve yükseklik niteliklerine göre değerlendirilen 12 , 19, 23 nolu fotoğrafların GKP'larının yüksek olduğu görülmektedir. Duvarların sürekliliği ve yükseklik algıları varıklarını daha etkili kılmaktadır. Dolayısıyla kentin sahip olduğu kendine özgü çehresini belirleyen, siluetine katkı sunan, bu sayede yerleşim yapısını oluşturan, kentin fiziksel yapısının önemli parçalarından olan duvarların algılanması, okunabilirliliği ve bıraktığı etki kent kimliğini tanımlanmasında önemli bir rol oynamaktadır.

GKP üzerinde en etkili olan parametreleri belirlemek için yapilan regresyon analizine göre, 7 ana model oluşmuştur. Bunlardan yedi parametrenin oluşturduğu 7. model en etkilidir. Burada, $R^{2}=, 387, F=||, 835$ ve $p=0,000$ olmak üzere, güzel $(\beta=0,460)$, bakımlı $(\beta=0,350)$, ilginç $(\beta=0,270)$, hareketli $(\beta=-0,370)$, sade $(\beta=0,352)$, rahatlatıc $(\beta=-0,253)$, ve doğal $(\beta=0,, 4 \mid 2)$, parametreleri en etkili parametreler olarak belirlenmiştir (Tablo 3). Mekânları oluşturan fiziksel çevre, öge ve bileşenlerin güzel, bakımlı, sade ve doğal olması, görsel kalitesini yüksek oranda etkilemektedir. Dolayısıyla regresyon analizi sonucu tercih edilirliği belirleyen 7 parametrenin, her bir duvarın güzellik ve doğalık değeri ile ilişkili olduğu da söylenebilir (Tablo 4).

Duvar görüntülerini değerlendirilmede kullanılan parametreler arasındaki ilişkiyi belirleme yönünden yapılan analiz çalışması sonucunda; güzel bulunan fotoğraf, aynı zamanda rahatlatıcı, etkili, dinlendirici olarak nitelendirilmiştir. Özellikle parametreler arasındaki korelasyon katsayılarına bakıldığında; çirkin/ güzel parametresinin sıkıcı/rahatlatıcı parametresi ile arasında $(0,952)$, sıkıcı/rahatlatıcı parametresi ile monoton/hareketli parametresi arasında $(0,946)$ ve sıkıcı/rahatlatıı parametresi ile sıradan/ilginç parametresi ile arasındaki korelasyon katsayısı $(0,940)$ yüksek çıkmıştır. Benzer şekilde yorucu/dinlendirici 
Tablo 4. Fotoğrafların GKP üzerinde en etkili olan sıfat çiftlerinin değerlendirilmesine ilişkin regresyon analizi ( $\left.{ }^{*}<<0.0 \mathrm{I}\right)$

\begin{tabular}{|c|c|c|c|c|c|c|c|}
\hline Model no & Model parametreleri & R2 & B & Beta $(\beta)$ & $\mathbf{t}$ & $\mathbf{F}$ & Önemlilik* \\
\hline 1 & Güzel & 0,257 & 0,137 & 0,507 & 4,853 & 23,552 & 0,000 \\
\hline \multirow[t]{2}{*}{2} & Güzel & 0,304 & 0,138 & $0,5 \mathrm{I} I$ & 5,378 & \multirow{2}{*}{14,626} & \multirow{2}{*}{0,000} \\
\hline & Bakımlı & & $-0,051$ & $-0,216$ & $-2,880$ & & \\
\hline \multirow[t]{3}{*}{3} & Güzel & 0,347 & 0,133 & 0,492 & 2,759 & \multirow{3}{*}{11,666} & \multirow{3}{*}{0,000} \\
\hline & Bakımlı & & $-0,080$ & $-0,336$ & $-2,489$ & & \\
\hline & İlginç & & 0,061 & 0,240 & 4,925 & & \\
\hline \multirow[t]{4}{*}{4} & Güzel & 0,403 & $0,14 \mid$ & 0,521 & $-2,919$ & \multirow{4}{*}{10,987} & \multirow{4}{*}{0,000} \\
\hline & Bakımlı & & $-0,076$ & $-0,320$ & 2,075 & & \\
\hline & İlginç & & 0,081 & 0,319 & 5,011 & & \\
\hline & Hareketli & & $-0,065$ & $-0,257$ & $-2,119$ & & \\
\hline \multirow[t]{5}{*}{5} & Güzel & 0,542 & 0,025 & 0,028 & 6,435 & \multirow{5}{*}{$10,50 \mid$} & \multirow{5}{*}{0,000} \\
\hline & Bakımlı & & 0,051 & 0,163 & $-3,808$ & & \\
\hline & İlginç & & 0,025 & $-0,098$ & 3,698 & & \\
\hline & Hareketli & & 0,026 & 0,099 & $-3,211$ & & \\
\hline & Sade & & 0,027 & $-0,089$ & 3,262 & & \\
\hline \multirow[t]{6}{*}{6} & Güzel & 0,593 & 0,170 & 0,024 & 7,012 & \multirow{6}{*}{ II,087 } & \multirow{6}{*}{0,000} \\
\hline & Bakımlı & & $-0,|I|$ & 0,025 & $-4,445$ & & \\
\hline & İlginç & & 0,132 & 0,028 & 4,687 & & \\
\hline & Hareketli & & $-0,051$ & 0,030 & $-1,713$ & & \\
\hline & Sade & & 0,104 & 0,030 & 3,410 & & \\
\hline & Rahatlatıcı & & $-0,089$ & 0,033 & $-2,738$ & & \\
\hline \multirow[t]{7}{*}{7} & Güzel & 0,387 & 0,231 & 0,460 & 4,233 & \multirow{7}{*}{11,835} & \multirow{7}{*}{0,000} \\
\hline & Bakımlı & & 0,186 & 0,350 & 3,360 & & \\
\hline & İlginç & & 0,183 & 0,270 & 3,352 & & \\
\hline & Hareketli & & $-0,163$ & $-0,370$ & $-3,406$ & & \\
\hline & Sade & & 0,176 & 0,352 & 2,638 & & \\
\hline & Rahatlatıcı & & $-0,133$ & $-0,253$ & $-2,426$ & & \\
\hline & Doğal & & 0,207 & 0,412 & 3,901 & & \\
\hline
\end{tabular}

ve çirkin/güzel parametresi arasında $(0,929)$, çirkin/güzel ve yorucu/dinlendirici parametresi arasında $(0,926)$ ve çirkin/güzel ve etkili/etkisiz parametresi arasındaki korelasyon katsayısı da $(0,918)$ yüksek olduğu görülmektedir (Tablo 5$)$.

\section{Sonuç}

İnsanların bireysel ve toplumsal olarak yaşadıkları kentin, kentsel mekanların, kent ögelerinin farklııklarını, özgünlüklerini algılamaları önemlidir. Çevre bütün olarak insanları kendini ifade etmeye, çevre ile ilişki kurmaya, fiziksel çevresini geliştirmeye ve güzelleştirmeye teşvik etmelidir. Kentsel kimlik öncelikle kentte yaşayanların farkındalığı ve kabullenmesi ile geliştirilebilecek bir kavramdır. Kent coğrafyası, kültürel yapısı, mimari yapısı, yerel gelenekleri, yaşam biçimi bir bütün olarak kent kimliğine katkı sunar. Kenti bir bütün olarak göremediğimizde, kentin sorunlarına geçici çözümler bulmaktan öteye gidemeyiz.

Bu çalışmada, Artvin İli'nin topoğrafik yapısının koşulu olarak oluşmuş duvarların yaşayanlar tarafından nasıl algılandığı sorgulanmıştır. Kent merkezine ulaşan taşıt ve yaya yolu üzerinde duvarların yoğun kullanımı, kent kimliği açısından değerlendirilebilir kılmaktadır. İnsanların duvarları nasıl algıladığı, bu konudaki farkındalıkları duvarların kimlik elemanı olarak geliştirilmesine katkı sunacaktır. Yapılan çalışmada; doğal malzeme ile yapılmış, üzerinde doğal bitki örtüsünü bulunan duvarların görsel kalite puanı yüksek çıkmıştır. Kent kullanıcıları, doğal çevre güzellikleri ile dikkat çeken kentin duvarlarının çevreye uygun olmasını bu niteliklerin görsel kalite açısından daha 
Tablo 5. Parametre çiftleri arasındaki ilişki (Spearman korelasyon analizi)

\begin{tabular}{|c|c|c|c|c|c|c|c|c|c|c|}
\hline & & $\begin{array}{l}\text { Çirkin/ } \\
\text { Güzel }\end{array}$ & $\begin{array}{l}\text { Karmaşık/ } \\
\text { Sade }\end{array}$ & $\begin{array}{c}\text { Sıkıcı/ } \\
\text { Rahatlatıcı }\end{array}$ & $\begin{array}{c}\text { Sıradan/ } \\
\text { İlginç }\end{array}$ & $\begin{array}{c}\text { Bakımsızl } \\
\text { Bakımlı }\end{array}$ & $\begin{array}{l}\text { Yapayl } \\
\text { Doğal }\end{array}$ & $\begin{array}{c}\text { Yorucul } \\
\text { Dinlendirici }\end{array}$ & $\begin{array}{c}\text { Etkisizl } \\
\text { Etkili }\end{array}$ & $\begin{array}{l}\text { Monoton/ } \\
\text { Hareketli }\end{array}$ \\
\hline Çirkin/ & Korelasyon katsayısı & 1,000 & $0,757^{* *}$ & $\underline{0,952} * *$ & $0,895^{* *}$ & 0,836 ** & $0,565^{* *}$ & $\underline{0,926}^{* *}$ & $\underline{0,918}^{* *}$ & $0,898 * *$ \\
\hline Güzel & Önem derecesi & - & 0,000 & 0,000 & 0,000 & 0,000 & 0,004 & 0,000 & 0,000 & 0,000 \\
\hline Karmaşık/ & Korelasyon katsayısı & $0,757^{* *}$ & 1,000 & 0,676 ** & $0,576 * *$ & $0,668 * *$ & $0,532 * *$ & $0,758 * *$ & $0,729 * *$ & $0,513 * *$ \\
\hline Sade & Önem derecesi & 0,000 & - & 0,000 & 0,003 & 0,000 & 0,007 & 0,000 & 0,000 & 0,010 \\
\hline Sıkıcı/ & Korelasyon katsayısı & $0,952 * *$ & $0,676^{* *}$ & 1,000 & $\underline{0,940} * *$ & $0,754 * *$ & $0,624 * *$ & $0,929 * *$ & $0,89 \mid * *$ & $\underline{0,946}$ ** \\
\hline Rahatlatıcı & Önem derecesi & 0,000 & 0,000 & - & 0,000 & 0,000 & 0,001 & 0,000 & 0,000 & 0,000 \\
\hline Siradan/ & Korelasyon katsayısı & $0,895^{* *}$ & $0,576 * *$ & $\underline{0,940} * *$ & 1,000 & $0,776 * *$ & $0,479 *$ & $0,846 * *$ & $0,870 * *$ & $\underline{0,914}{ }^{* *}$ \\
\hline İlginç & Önem derecesi & 0,000 & 0,003 & 0,000 & - & 0,000 & 0,018 & 0,000 & 0,000 & 0,000 \\
\hline Bakımsız/ & Korelasyon katsayısı & $0,836 * *$ & $0,668 * *$ & $0,754 * *$ & $0,776 * *$ & 1,000 & 0,154 & $0,693 * *$ & $0,824 * *$ & $0,684 * *$ \\
\hline Bakımlı & Önem derecesi & 0,000 & 0,000 & 0,000 & 0,000 & - & 0,472 & 0,000 & 0,000 & 0,000 \\
\hline Yapay/ & Korelasyon katsayısı & $0,565^{* *}$ & $0,532 * *$ & $0,624 * *$ & $0,479 *$ & 0,154 & 1,000 & $0,737^{* *}$ & $0,578 * *$ & $0,636 * *$ \\
\hline Doğal & Önem derecesi & 0,004 & 0,007 & 0,001 & 0,018 & 0,472 & - & 0,000 & 0,003 & 0,001 \\
\hline Yorucu/ & Korelasyon katsayısı & $0,926 * *$ & $0,758^{* *}$ & $\underline{0,929} * *$ & $0,846 * *$ & $0,693 * *$ & $0,737^{* *}$ & 1,000 & $0,876 * *$ & $0,875 * *$ \\
\hline Dinlendirici & Önem derecesi & 0,000 & 0,000 & 0,000 & 0,000 & 0,000 & 0,000 & - & 0,000 & 0,000 \\
\hline Etkisiz/ & Korelasyon katsayısı & $0,918 * *$ & $0,729 * *$ & $0,89 \mid * *$ & $0,870 * *$ & $0,824 * *$ & $0,578 * *$ & $0,876 * *$ & 1,000 & $0,845^{* *}$ \\
\hline Etkili & Önem derecesi & 0,000 & 0,000 & 0,000 & 0,000 & 0,000 & 0,003 & 0,000 & - & 0,000 \\
\hline Monoton/ & Korelasyon katsayısı & $0,898 * *$ & $0,513^{*}$ & $\underline{0,946} * *$ & $\underline{0,914} * *$ & $0,684 * *$ & $0,636 * *$ & $0,865 * *$ & $0,845^{* *}$ & 1,000 \\
\hline Hareketli & Önem derecesi & 0,000 & 0,000 & 0,000 & 0,000 & 0,000 & 0,001 & 0,000 & 0,000 & - \\
\hline
\end{tabular}

önemli olduğunu düşünmektedir. Doğal malzeme kullanımı sürdürülebilirlik açısından da önemlidir. Yenilenebilir, çevreye zarar vermeyen malzemeler kentin ruhuna denk düşmektedir. Fakat özellikle yol boyu sürekliliği fazla olan duvar yüzeylerinde yeşil doku çeşitliliği sağlanabilir. Mevsimsel olarak çiçeklenen bitkilerin kullanımı duvarları, dönemsel olarak hareketlendirecektir.

Çalışmada insan ölçeğini çok fazla aşan yükseklikteki betonarme duvarların, üzerinde su tahliyesi için kullanılan boruların, düzensiz reklam afişlerinin bulunduğu duvarların görsel kalite puanları düşük çıkmıştır. Özellikle teknik zorunluluklardan kaynaklanan yüksek betonarme duvarlar yapılırken, estetik açıdan tasarımsal yaklaşılmalıdır. Kademeli duvar yapmak, yapısal ve bitkisel yaklaşımlı (Aksu ve Acar, 2010) çözümler öretmek gerekmektedir. İlan panoları duvarlar yüzeyinde sürekliliği-yoğunluğu, boyutları, konumları dikkate alınarak kullanılmalıdır.

Doğal elemanlarla yapılan duvarların yanında, üzerinde resim, figür, yapısal objeler (çeşme, hayvan heykelleri, yapay şelaleler gibi) bulunan duvarların görsel kalite puanları yüksek çıkmıştır. Kent kullanıcıları kentsel mekanlarda farklı görüntüler de görmek istemektedir. Bunların duvar yüzeyinde kullanımları için sonsuz seçenekler üretilebilir. Fakat önemli olan insanlar üzerinde bıraktığı olumlu etkiler, verilmek istenen mesajlar, top- lum yapısına ve çevreye uygun görüntüler oluşturmasıdır. Yapısal objelerin duvarlar yüzeyinde görsel kirlilik yaratmaması için konumsal olarak hangi duvar yüzeyinin seçilmesi gerektiği, duvarın boyutu-sürekliliği, malzemesi önemlidir. En önemlisi bu uygulamaların tasarım ilkeleri dikkate alınarak yapılmasıdır.

Araştırma alanı olarak seçilen, kent merkezine ulaşan ve yol boyunca yer alan duvarlar görsel açıdan değerlendirilebilir potansiyele sahiptir. "Yol üzerinde mor salkımlı duvarın karşısında", "üzerinde geleneksel motiflerin olduğu duvarı geçince" gibi ifadelerle mekanları anımsatmak veya karşıdan bakınca yol güzergahını belirleyen duvarları dikkat çekici kılmak tüm kente olumlu etkileyecektir. Çoğrafi koşullardan kaynaklı, zorunlu olarak oluşan duvarlar, kent için anlamlı hale gelecektir. Söz konusu duvarların görsel kalite açısından ele alınarak iyileştirilmesi, duvarların ve mekanların hatırlanabilirliğini artıracak, bu bağlamda kent kimliğine önemli katkılar sağlayacaktır. 


\section{KAYNAKLAR}

Acar, C., Demirbaş, E., Dinçer, P., Acar, H. (2003). “Anlamsal Farklılaşım Tekniğinin Bitki Kompozisyonu Örneklerinde Değerlendirilmesi”. Turkish Journal Of Forestry. A(1), 15-28.

Acar, C., Güneroğlu A. N. (2009). “Trabzon Kentindeki Çizgisel Bitki Kompozisyonlarinin Tür Çeşitliliği İle İşlevsel Ve Görsel Değerleri Üzerine Bir Araștirma”. Ekoloji Dergisi, 18(72).

Aksu, Ö. V., Acar, C. (2010). Kent İçi İstinat Duvarlarinin Peyzaj Mimarliği Açisindan İrdelenmesi: Trabzon Kenti Örneği. Artvin Çoruh Üniversitesi Orman Fakültesi Dergisi, 11(2), 1-11.

Aksu, Ö. V. (2012). Kent mobilyaları tasarımında özgün yaklaşımlar. İnönü Üniversitesi Sanat Ve Tasarım Dergisi, 2(6), 373-386.

Alexander, C., Ishikawa, S. \& Silverstein, M. (1977) A Pattern Language?Towns Buildings Construction (New York: Oxford University Press).

Arriaza M, Canas-Ortega JF, Canas-Madueno JA and Ruiz-Aviles P. (2004). Assessing the visual quality of rural landscapes. Landscape and Urban Planning; 69(1):115-25

Başal, M., Memlük, Y., Yılmaz, O. (1993). Peyzaj Konstrüksiyonu, Ankara Üniversitesi Ziraat Fakültesi Yayınları: 1322, Ders Kitabı: 381, 170S., Ankara

Baykan, G. (2006).Şehircilik-Planlama-Tasarlama- Mimarlık-Peyzaj, Planla$\mathrm{ma}, 4,19-22$.

Bayraktar, N., Tekel, A., Ercoşkun, Ö. Y. (2008). Ankara Atatürk Bulvarı üzerinde yer alan kentsel donatı elemanlarının sınıflandırılması, değerlendirilmesi ve kent kimliği ilișkisi. Gazi Üniv. Müh. Mim. Fak. Dergisi, 23(1), 105-118.

Dascalu, D.M. (2011). Landscape Effects of Urban Furniture Tectures. Bulletin UASVM Horticulture 68(1), 324-331.

Eminağaoğlu, Z., Yavuz, A. (2005). Artvin kent dokusunda yeşil alan incelemesi. Artvin Coruh UEniversitesi Orman Fakueltesi Dergisi, 6(1), 191202.

Eren, A.G.E., T., Alpak, E. M., Düzenli, T. (2018). Mevsimsel Bitki Görünümlerinin Tercih Ve Algisal Farklilıklarının Belirlenmesi. Volume: 3, Issue: $1, \mathrm{P}: 145-154$

Göregenli, M. (2010). Çevre Psikolojisi: İnsan-Mekan İlişkileri, İstanbul: Bilgi Üniversitesi Yayınlar1.

Hornbeck, J.W. (1973). Storm flow from hardwood-forested and cleared watersheds in New Hampshire Water Resour. Res., 9 (1973), pp. 346-354

İnceoğlu, M., \& Aytuğ, A. (2009). Kentsel Mekânda Kalite Kavramı. Megaron, $4(3)$.

İnceoğlu, M,. (2010), Tutum, Alg1 ve İletişim, İstanbul, Beykent Üniversitesi Yayınları

Kahvecioğlu, H. L. (1998). Mimarlıkta imaj: mekansal imajın oluşumu ve yapısı üzerine bir model (Doctoral dissertation, Fen Bilimleri Enstitüsü).

Kalipsiz, A. (1981). Istatistik Yöntemler. I.Ü. Orman Fak., Yayın, (2837/294).

Kalmbach, K.L, Kielbaso, J. J. (1979). Resident attitudes toward selected characteristic of street tree planting J. Arbor 5(6):124-129

Kayapa, N. ve Tong, T., (2011), "Sanal Gerçeklik Ortamında Alg1", Sigma 3, 348-354.

Lynch, K. (1981) A Theory of Good City Form. Cambridge, Massachusetts, and London: The MIT Press.

Lynch, K. (1960). The Image of the City, Cambridge, Mass: MIT Press.

Lynch, K. (2010). Kent İmgesi, çev: İrem Başaran,İstanbul: Türkiye İş Bankası Kültür Yayınları.

Norberg - Schulz, C. (1980). Genius Loci: Towards a Phenomenology of Architecture, New York: Rizzoli.

Norberg-Schulz, C. (1971). Existence, Space and Architecture, NY: Praeger.

Ocakçı, M., ve Türk, Y. A. (2012). Kentsel kimlik. Kentsel Planlama Ansiklo- pedik Sözlük (derleyen: Melih Ersoy), Ninova Yayınları, İstanbul.

Osgood, C.E, Suci, GJ Tannenbaum, P. H. (1957). The measurement of meaning. The University of Illinois Press New York

Önem, A. B., Kilincaslan, I. (2010). Haliç bölgesinde çevre algılama ve kentsel kimlik. İTÜ DERGİSİ/ a, 4(1).

Özen, A. (2006). Mimari sanal gerçeklik ortamlarında alg1 psikolojisi. Bilgi Teknolojileri Kongresi IV, Akademik Bilişim.

Özgüç, İ. (1999). TEM Hadımköy-Kınalı arası peyzaj planlaması üzerinde görsel araştırmalar. İstanbul Üniversitesi Orman Fakültesi Dergisi, 49(2), 115-132.

Rapoport, A,. (1990), The Meaning Of The Built Environment, A Nonverbal Communication Approach, Tucson, The University Of Arizona Pres

Relph, E. (1976). Place and Placelessness, ABD: Pion.

Sarı, D., Karaşah, B. (2015). Hatila Vadisi Milli Parkínda (Artvin) yer alan farklı vejetasyon tiplerinin görsel değerlendirmesi üzerine bir çalışma. Turkish Journal of Forestry, 16(1), 65-74.

Solak, S. G. (2017). Mekân-Kimlik Etkileşimi: Kavramsal Ve Kuramsal Bir Bakış. Manas Sosyal Araştırmalar Dergisi Manas Journal Of Social Studies (Mjss), 13.

Januchta-Szostak, A. (2010). The Role of Public Visual Art in Urban Space Recognition. ISBN 978-953-307-044-5, pp. 140, INTECH,

Tanrıverdi, F. (2001). Peyzaj Mimarlığı Bahçe Tanıtımı Temel İlkeleri ve Uygulama Metotları.

Tversky, T., Geisler, W.S., Perry, J.S.(2004). Contour grouping: Closure effects are explained by good continuation and proximity. Vision Research. 2004;44:2769-2777.

Tversky, B. (2000). Remembering spaces, Handbook of memory (pp. 363 378). New York: Oxford University Press

Uzun, G., 1997. Peyzaj Konstrüksiyonu I. Çukurova Üniversitesi Ziraat Fakültesi Yayın No:137, 256s.

Ünlü, T. S. (2017). Kent Kimliğinin Oluşumunda Kentsel Bellek ve Kentsel Mekan İlişkisi: Mersin Örneği, Planlama, 27(1):75-93.

Val, G.F., Atauri, J.A., Lucio, J.V. (2006). Relationship between landscape visual attributes and spatial pattern indices: a test study in mediterranean - climate landscapes. Landscape and Urban Planing, 77: 393 -407 